\title{
Russell and feminism
}

\author{
by Katharine Tait
}

I HAVE BEEN asked to speak to you about Russell and feminism. An easy topic, I thought. Everybody knows he was in favour of italmost literally born to it: delivered by the first woman doctor, godfathered by John Stuart Mill; and the son of two ardent feminists. His mother made speeches for women's suffrage in the 1860 s. He was raised by women, nurtured by two very strong-minded grandmothers and an aunt. And as early as 1907 he stood for Parliament as a women's suffrage candidate.

Obviously, he must have been a feminist. All I needed to do was to find enough evidence of it to fill up half an hour's talk. I turned to the sources I had at hand.

I looked in the index of Ronald Clark's biography of Russell. No entry for "feminism". No entry for "woman". And under "women's suffrage", only an account of the awful Wimbledon by-election of 1907 in which he stood for women's suffrage. His advocacy provoked violent opposition, and he lost. That is all I found in Clark, so I concluded that perhaps Clark had a masculine bias.

Then I went to the Autobiography and looked in all three volumes, under "feminism", under "woman" and under "women's suffrage", and I didn't find anything. Then I began to think: what am I going to do? How am I going to find out anything to tell these people except just what I happen to remember? So I tried all the other odds and ends of Russell books that I have-and I found nothing. I looked at the collections of essays I have, and in the collections that I have there is nothing really about feminism. I wrote to Ken Blackwell and asked him if he could produce something for me, but then I had to go ahead and write my speech before he answered. Most of what he finally produced was what I already knew.

I looked in Russell's book, On Education; there were really only passing references to feminism in it. I looked in The Conquest of 
Happiness; I didn't find much in that. I looked in Marriage and Morals and found a description of the problems of women, but no prescription for what to do about them.

Well, how important was feminism to Russell?

I think we had better take a look at the evidence I did find. This is a very rough survey, because, although I knew him, I am not a Russell expert; whenever I come to McMaster I speak with fear and trembling, knowing there are so many experts here. I'll ask them to fill in afterwards whatever I have omitted. There are three kinds of evidence: what he wrote, what he did, and what he felt. And I am going to begin with what he did, with his actions. I'm going to go through his life rather superficially in terms of the women-at least some of them!-that he was involved with. Maybe that is just my own bias, but it seems an appropriate way to deal with this topic.

Alys, his first wife, was older than he was, quite a bit older, and she was a feminist already when he met her. He was really, absolutely, romantically in love. It was the first passion of his life, and I would have thought that she would have been an important influence on his views about women. Actually, when you read his letters to her, in spite of his being five years younger, they are appallingly condescending - as though he were already a famous man forming the character of an ignorant young thing. He was always talking about how he was going to form her mind and teach her to be this, that, and the other thing. Had I been Alys I think I wouldn't have married him. She believed, at least theoretically, in free love. She believed actively in votes for women and in equal rights for women, and she helped him in his election campaign in 1907. But hers was only a public and theoretical belief; there is no evidence that either of them ever considered any career for her other than being his wife. Theoretically, she was to be equal in all ways, but she was always his dependent. She was always his backer-up, and never, ever, his rival.

It doesn't seem to me that when he was young he was really a very passionate feminist of any kind. He was in favour of votes for women, because that was right and proper and just; he was in favour of votes for everybody, even including women. He didn't approve of the suffragettes, the violent ones who engaged in civil disobedience. ( $\mathrm{He}$ changed as he got older.) In writing to somebody about his standing for Parliament in 1907, he called it "a howling joke", ${ }^{1}$ and he said that if there were any chance of being elected he would not be standing. He said later that the emancipation of women was "part of

' Ronald W. Clark, The Life of Bertrand Russell (London: Cape/Weidenfeld and Nicholson, 1975; New York: Knopf, 1976), p. 122. the democratic movement"; democratic theory "made it impossible to find any logical answer to the demands of women". ${ }^{2}$ It was really a simple matter of human justice and not the rights or interests of women as women.

I moved along to see if he got more involved, and I considered his long affair with Lady Ottoline Morrell. It didn't seem to me that feminism had any relevance in that affair. And then there was Colette, Lady Constance Malleson, and there it is relevant in a negative way, because she was an actress and she wouldn't give up her career and she didn't want to have children. For that reason, or so he says, he gave her up; he wanted a wife who was going to be a mother and provide him with children and not put something else ahead of this. These two, actually, were women he could not dominate and possess. In a sense they were emancipated women, never anyone's mere wife, nor willing to abandon all for love of Russell. They were individuals.

Then he took up with Dora Black. She was my mother. She was willing to have children, but she also wanted a career. She was well on her way to having a career and she didn't want to get married, considering marriage a legal apparatus set up by men to keep women under their control. Although she was very willing to have children, she didn't want a proper, ordinary marriage.

I would like to make a digression here to talk about Dora, because she is always my touchstone for genuine feminism. She really believed in the value of women as women. She didn't want them to be mere companions of men; she wanted them to be in every way equal, in every way influential. She was very ambitious when she was young; she was very confident; she was a bit arrogant; and she was determined to make a mark on the world as a female human being. She thought that women ought to be deeply involved in politics, because there were so many things they understood that men did not. Men had made a mess of the world, and it was time the women got a chance to straighten it out. They would understand much better about peace and war, and hunger, and birth control, and allowances for children, and that sort of thing, than any of the men who had been running the country. What she said was that she "wanted women not only to have equality and rights, but also for the very essence of what they represent to count in politics and society". ${ }^{3}$ And she went on to

2 Bertrand Russell, Marriage and Morals (London: Allen and Unwin, 1929), pp. 65, 66; (New York: Liveright, 1929), pp. 78, 80.

${ }^{3}$ Dora Russell, The Tamarisk Tree (London: Elek/Pemberton, 1975; New York: Putnam's Sons, 1975), p. 295. 
8 Russell, nos. 29-32 (1978)

say:

The prestige of masculine work has led women to despise and denigrate their own special contribution. For women must not merely imitate men. Women have more to give than performing any job in society like neutered robots.... There should be in all things, intertwining of male and female minds. Not, as at present, that women may approximate more to what men call learning, but that men may also discover within their own psyche those faculties of intuition and imagination so long neglected as to be near atrophy. (Tamarisk Tree, p. 296)

She always set great store by motherhood, the one indubitable female prerogative. That was what surprised my father when he first met her. She was obviously a very intelligent and very well-educated and very ambitious young woman, but what she said was that she wanted to have children, and in those days such women didn't, because that meant cutting themselves off from a career. They couldn't have children without marriage, and if they married they were expected to give up their work. It was a remarkable thing for an intelligent young woman to say, "I want to get married and have children." Usually what happened was that after a while the desire crept up on them, they wished they could, and they thought they might as well, and so they did. Even when I was as school I remember people talking about women who breastfed their babies, saying that they were no better than cows, any cow can do that. That is the sort of attitude against which Dora wanted to have babies. She considered motherhood a symbol of the fruitfulness of nature. She believed that men are all interested in the mind and the machine, while women are the real, ongoing, creative, productive sex. And they should stay that way. When people got married it would be an equal partnership; they would be equally free, but they wouldn't be interchangeable; one would be a man and the other a woman. That seems to me real feminism. You assert the right of the woman to be every bit as influential, every bit as free, every bit the equal of the man, but still not a substitute man. It is against this body of belief and the life that went with it that I measure my father's engagement with feminism.

He married her; and in order to marry such a dynamo of conviction, he must have had at least sympathy with her ideas. But after they got married she was the one who yielded. She gave up her career. She gave up her objections to marriage and she became just his wife and the mother of his children. For her it was a real sacrifice. "Women who have been free", she wrote in one of her books,
Russell and feminism

"remember the horror of the approach to marriage. ... As a Labour Minister is corrupted by court dress, so is a free woman by the marriage-contract. Nothing but our desire for children would make us endure it."4 She felt things strongly!

They did have children and then they started the school for the two children, and in that they were equal partners, equal in all the work and responsibility. In my opinion neither one was really above the other; but in the eyes of the world (and possibly in his eyes too) he was far more famous, and he was a man, and obviously it was his school, and she was just his wife; she was the first mate to his captain. "Bertie did not really believe in the equality of women and men", she concluded. " . . he believed the male intellect to be superior to that of the female. He once told me that he usually found it necessary to talk down to women" (Tamarisk Tree, p. 291). This passage reminds me of the tone of his letters to Alys when he was educating this common person to be a suitable wife to himself.

My mother's final verdict on the champion of free love and the rights of women:

... Bertie was an old-fashioned husband. His first need was for a mother of his child, his pride to support them both; he accepted as normal, and was very dependent upon, his wife's management of his household and domestic affairs. Beyond this he did not much explore the inner workings of the female psyche, but would minister to a mind if it bore resemblance to that of the superior male.... When Bertie spoke of a spiritual bond, he did mean that he wanted two hearts to beat as one; he sought a wife who would not assert her independence, but would be at one with him in everything that he thought and did. Possibly this miraculous union is what we all seek, but all too rarely find. (Tamarisk Tree, p. 294)

I would like to put in a little personal aside here. As child, I preferred my father to my mother; I was always "his child" and "his daughter". But I think she understands human nature a lot better than he did, and on the subject of women I think she is far more right than he was. She makes a lot more sense.

A few years after founding Beacon Hill School, they parted. They had thought they could be utterly free and have any kind of independent affairs they wanted and that it wouldn't make any difference to the marriage partnership or the raising of the children. But it did

${ }^{4}$ Dora Russell, Hypatia, or Women and Knowledge (London: Kegan Paul, Trench, Trubner, 1925; New York: Dutton, 1925), pp. 38-9. 
make a difference, so they parted and were bitterly divorced.

After that there were two more wives, Peter and Edith; both of them were very strong-minded women, but both of them were just wives. Four wives, in all; and each one played only a supporting role. Obviously he needed a full-time wife, but so does any working woman. When I first went out to work, I would come home and say, "My God, I need a wife around here". He needed one too. He was important. He needed someone to look after him, help him, support him, run the household, and care for the children. He was much too valuable to waste his time on mending socks and doing the washing and stuff like that. Not because he was a man, but because he was Bertrand Russell. It would have been a horrible waste to turn him into a washing machine. In his particular case, there was a need for someone to take care of him.

That, in outline, is what he did about feminism. And sometimes I think that the outline's shape is zero, but perhaps that's not fair. What did he say about it? As you know, he wrote almost constantly and his writings were very influential. Here I will have to be corrected afterwards by the experts, because I have only looked in the obvious places that I happen to have. In 1907, the same year he stood for Parliament, he wrote an essay, which has been given the title "The Status of Women", 5 and the gist of it is that votes for women are a pure matter of justice. Women should be given the vote just as the working man has been given the vote. If people say that women are irresponsible and that they will vote by their emotions, they always said that about the working man and we know that in his case the prediction did not turn out to be true. The same will happen with women; when we have given them responsibility, they will measure up and we will find that they are not what we presently think they are. All of which is perfectly true and perfectly just and at that time needed very much to be said. But it wasn't the women he was interested in, it was justice.

In his book On Education, he writes, "I make no distinction between male and female excellence". ${ }^{6}$ He thinks that girls, like boys, ought to learn physical courage and ought to do physical exercise, and they ought not to be taught to be timid and dependent because this, when they grow up, will mess up their sex lives and the sex lives of their husbands too. Most of the time, and all through the

${ }^{5}$ Bertrand Russell, "[The Status of Women]", Russell, no. 14 (Summer 1974), 3-12.

6 Bertrand Russell, On Education, Especially in Early Childhood (London: Allen and Unwin, 1926), p. 48. American edition: Education and the Good Life (New York: Boni and Liveright, 1926), p. 60 . book, he is talking about "the intelligent boy" and "boys will do" and "boys will probably" and "the intelligent boy can be got to do this". As Dora says, what matters to him is the male mind. That is what he was really after.

In The Conquest of Happiness, presumably written for both sexes, we hear about "the man who ...", "the man who has problems with his job", "the man who seeks intoxication", "the man who does this", and "the man who does that". And the last chapter is called "The Happy Man". Now I am not among those who think that you must say "personkind" instead of "mankind" or anything like that; but when Russell writes here about a man, he means a male man and not just a person. He does discuss the problems of women, but the discussion is only a part of a chapter on the family, and the family is discussed as being necessary to man's happiness. He draws a very sympathetic picture of the awful life that women led in the bad old days when they could only marry and be dependent wives or stay at home and be dependent and frustrated spinsters. And then he goes on to describe the pleasant life of the modern unmarried young woman of the late 1920s who could have a job of her own and money of her own and a free and pleasant life, "... so long as she can keep free from the desire for children. But if this desire overwhelms her, she is compelled to marry and almost certainly to lose her job.... After having enjoyed independence, she finds it galling to have to look to another for every penny of necessary expenditure". 7 If she is rash enough to go ahead and do it anyway, she is confronted by "... a new and appalling problem, namely the paucity and bad quality of domestic service" (pp. 188 and 190). She has to do everything herself or supervise these idiot maids all the time, and she becomes petty and small-minded. (How dated this sounds! There is the assumption that there will always be maids to be supervised and there is always total blindness to their exploitation. Only educated women matter, and they somewhat less than educated men.)

He states the problem of the woman with some sympathy, but he doesn't offer any solution, neither a solution personally for a woman nor a solution for society as a whole. And, although the book is called The Conquest of Happiness, he doesn't tell you how women are to conquer happiness. Moreover the problem of women only comes up in connection with man's desire for children, and maybe this is why, when I read the book, I found it so unhelpful.

In Marriage and Morals there is a whole chapter devoted to the

${ }^{7}$ Bertrand Russell, The Conquest of Happiness (London: Allen and Unwin, 1930), p. 188; (New York: Liveright, 1930), p. 189. 


\section{Russell, nos. 29-32 (1978)}

liberation of women. It gives a fairly general outline history, and then reviews the problems, but without passion and without recommendations. He begins with the logical necessity of granting women political equality because it is fair ad just, and the practical necessity of recognizing that they can earn their own living and they $d o$, and they can manage on their own and they $d o$. So the reader might just as well accept what he is saying: there is no reason why women should not have equal rights. Beyond this he makes no recommendation; it was not one of the problems close to his heart. Most of the chapter, like most of the book, is taken up with problems of sexual freedom, for women as well as for men. That was the problem at that time. It makes strange reading now, because apparently we have arrived where he wanted to go. In my present job I see a lot of students, and I would say that they don't have any particular problems of sexual freedom. Supposing that we approve of where they have arrived, we must say that he has been successful.

One problem which did engage his interest-perhaps because of his personal involvement in it through Dora-was that of working wives and their children, and how to deal with them. That is still a problem. At that time it was taken for granted or even required that a woman would give up her job on marriage. She would lose her income and she would lose her independence; she would be poor and stuck at home. That was 1930 . When my children were young in Washington, in 1960 , the first grade teacher, who was a married woman, had to resign her job after the first two months of pregnancy, because it was regarded as too embarrassing for her and the children. It was all right for the children to go home and see their mothers producing all over the place, but teachers NO! Some changes require a lot of time.

He went on to ask, who would take care of the children if women went on working? His solution was to make motherhood a paid, preferably trained, profession for those who wanted it, allowing other women to remain childless and to go on working "outside the home", as we say nowadays. "There is ... on the part of the individual woman", he wrote, "such a horror of the home that I think most women would very much prefer to be enabled to continue the work they were doing before marriage, rather than be paid for taking care of their own children" (Marriage and Morals, pp. 169 and 213). Women, he thought, would be willing to care for children in daycare centres, professionally, but not at home as their own children. "It is probable", he went on, "that a high civilization will not in future be possible to maintain unless women are paid such sums for the pro- duction of children as to make them feel it worth while as a moneymaking career" (pp. 170 and 215-16). He sounds quite up-to-date here; that's about where we are now, and his solution might appeal to many present-day feminists. But there has been a strange interlude in between: after the second war, many women rushed back home and produced children like mad (as I did myself). I am not sure, in consequence, that we can predict that things will go on as they are any more than they went on as they were when he was making predictions. Possibly, when the few children that you plan to have are grown up, they will all rush back to the hearth.

One solution that he never considered, despite his passionate interest in his own children and his deep involvement with us, was joint care by both parents. "It has always been recognized", he said,

"that fathers cannot be expected to do very much for their children... The relation of the mother to the child will have in the future to resemble more and more that which at present the father has, if women's lives are to be freed from unnecessary slavery and children are to be allowed to profit by the scientific knowledge which is accumulating as to the care of their minds and bodies in early years. (Conquest of Happiness, pp. 206-7 and 208)

In addition, he thought that most women were not really qualified to care for children properly without special training in psychology and nutrition and exercise, so that, apart from the fact that they wouldn't want to, if they did want to, they wouldn't do it very well. It would be much better to make some other arrangement. And he really couldn't imagine any social transformation sufficient to allow for joint care, and taking turns, and alternate work hours, and the things that people are groping towards now. Even now, not many of us can really imagine how it can be worked out, though we may think it desirable. I see the problem clearly in the lives of my own children. At that time it was far beyond anybody's dreams.

I come now to the last part of my talk: what did Russell really feel about feminism? Maybe here I have something of my own to contribute, because I knew him. And it seems to me, just as Dora said, that he was dominated by the male intellect. When we read his popular works, we can see his rational mind at work, sorting, ordering, reducing life to problems and principles and solutions, the way I can remember him talking. We can also see the limitations of this approach: in Marriage and Morals in one place he says: "You will read in the works of male novelists that women find physical pleasure in 
suckling their young; you can learn by asking any mother of your acquaintance that this is not the case..." (pp. 170 and 214-15). If he had asked his wife he would have got a different answer! He speaks with a lot of sympathy of the problems of women, but really it is an outsider's sympathy, as we might sympathize with somebody who is starving in India, though we can't really imagine what it feels like. He never, I think, had any idea what an agony my mother went through in choosing whether to marry him or not. He also hadn't much notion of all the disorder and improvisation that go with bringing up children; it cannot be done by a logical system or a logical theory, because they upset such things all the time.

He thought that we could solve all problems by a reorganization of society; he was always dealing with the broad surface of public policy and how we could improve society so that there wouldn't be these individual problems. He never dealt with the narrow depths of personal feeling. He could understand the necessity of justice for women, as for blacks, Indians, and Irishmen, and he could fight for it. But I don't think he ever understood women.

I am in danger of making a muddle here, and I should pause to clarify things. A feminist can perfectly well be general and public and social, and entirely concerned with changing laws and customs for the benefit of women; lots of feminists are, and they are genuine feminists. You need not understand a woman's heart to fight for justice for her. A feminist need not even understand women. But I am not sure that Russell was a feminist very deeply even in this limited way. His devotion was to liberty and justice and fairness for all, not just women-and in this I think he was right. There is no reason why women should be more equal than others. We do not need "reverse discrimination", only "fair play".

Finally, I want to speak a bit personally. The muddle I was about to make was in judging Russell's feminism by his understanding of women. They are really distinct, though they are easily confused, and I confused them for many years. My father probably did too. I think no one in his right mind could claim that my father understood women or even considered them the mental equals of men. They were romantic ideals for him; they were sexual partners; they were housekeepers; and they were mothers to his children. But I was none of those things. I was a daughter with what he would call "a first-class mind". I didn't fit any of these proper roles. The only thing he could do with me was to bring me up like a boy, and value me for such sexless virtues as courage, strength, intelligence, and diligence in school. It was very disappointing to him that I just blindly wanted the type of life from which my education should have liberated me. He never understood the value of what I wanted, what I had learned from my mother to want, which was the creation and development of human beings. He told a friend once that I, who was the most brilliant of his children, was wasting my time going to church and changing diapers. What he meant was wasting my mind, which was the only part of me that really mattered to him. Five books would have seemed to him more worth while than five children.

Let me read you a description out of The Conquest of Happiness of what he thought that I had done with my life. This passage is about the woman who has given up a career for marriage and motherhood:

... she becomes tied to her house, compelled to perform herself a thousand trivial tasks quite unworthy of her ability and training, or, if she does not perform them herself, to ruin her temper by scolding the maids who neglect them. In regard to the physical care of her children, if she has taken pains to become well-informed in this matter, she finds that it is impossible, without grave risk of disaster, to entrust the children to nurses, or even to leave to others the most elementary precautions in regard to cleanliness and hygiene, unless she can afford a nurse who has had an expensive training at some institute. Weighed down by a mass of trivial detail, she is fortunate indeed if she does not soon lose all her charm and three-quarters of her intelligence. Too often through the mere performance of necessary duties such women become wearisome to their husbands and a nuisance to their children. When the evening comes and her husband returns from his work, the woman who talks about her day-time troubles is a bore, and the woman who does not is absent-minded.

Some of this is terribly true, but...

In relation to her children, the sacrifices that she has made in order to have them are so present to her mind that she is almost sure to demand more reward than it is desirable to expect, while the constant habit of attending to trivial details will have made her fussy and small-minded. This is the most pernicious of all the injustices that she has to suffer: that in consequence of doing her duty by her family she has lost their affection, whereas if she had neglected them and remained gay and charming they would probably have loved her. (Conquest of Happiness, pp. 188-9 and 190-1) 
16 Russell, nos. 29-32 (1978)

I think that this passage describes what he thought I was doing with my life, from his point of view an utter waste. But I thought I was doing with it the most valuable thing I could as a woman, which was to produce valuable human beings. This is not what he had desired for his brilliant daughter, though it was quite good enough for his wives. He needed wives to do those things for him, but he hoped I might be more than some man's second fiddle.

I don't think he really was ever a feminist, and, in fact, I think he treated women terribly. He was a theoretical feminist, but in practice he was one of your larger-sized male chauvinists.

Of course this is not a balanced, objective view. It is unfair and one-sided and intended to provoke argument. I hope it does.

Cambridge, Mass. 